\title{
Применение пироксенового продукта обогащения вермикулит- лизардитовых отходов для ремедиации торфяной почвы в импактной зоне Кольской ГМК
}

\author{
Петрова А.Г. ${ }^{1}$, Слуковская М.В. ${ }^{2,3}$, Корнейкова М.В. ${ }^{4}$, Иванова Л.А. ${ }^{4,5}$, Кременецкая И.П. ${ }^{3}$ \\ I'Петрозаводский государственный университет, Петрозаводск, petrova_anna93@таil.ru \\ 2 Лаборатория природоподобных технологий и техносферной безопасности Арктики КНЦ РАН, \\ Anamumbl,slukovskaya.mv@gmail.com \\ ${ }^{3}$ Институт химии и технологии редких элементов и минерального сырья им. И.В. Тананаева КНЦ \\ PAH, Anamumbl \\ ${ }^{4}$ Институт проблем промышиенной экологии Севера КНЦ РАН, Anamumbl, korneykova.maria@gmail.com \\ ${ }^{5}$ Полярно-альпийский ботанический сад-институт им. H.A. Аврорина, Anamuты, ivanova_la@inbox.ru
}

Аннотация. Представлены результаты полевого эксперимента по ремедиации участка с высоко загрязненной торфяной почвой вблизи медно-никелевого комбината с использованием пироксенового продукта, полученного при обогащении вермикулит-лизардитовых отходов добычи флогопита (Мурманская обл.). На почвосмесях, содержащих 25-100 \% продукта, был сформирован растительный покров по технологии штабелирования с использованием вспученного вермикулита, полученного из тех же отходов. Оптимальными по влажности являлись варианты 50 и 100 \%. Результаты первого вегетационного сезона показали, что в варианте с соотношением минерального материала и торфяной почвы 1:1, растительный покров имел наибольшую продуктивность, а микробное сообщество - максимальную численность бактерий и микромицетов. Комплексный показатель токсичности имел значения меньше 1 в вариантах с 75 и 100 \% пироксенового продукта, а в варианте 50 \% составлял 3.3. По результатам первого года, перспективными подходами являются перемешивание минерального материала с торфяной почвой в пропорции 1:1 и формирование насыпного слоя.

Ключевые слова: ремедиация; тяжелые металлы; Субарктика; горнопромышленные отходы.

\section{Application of pyroxene product of vermiculite-lizardite waste beneficiation for remediation of peat soil in the impact zone of Kola Mining and Metallurgical Company}

\author{
Petrova A.G. ${ }^{1}$, Slukovskaya M.V. ${ }^{2,3}$, Korneykova M.V. ${ }^{4}$, Ivanova L.A. ${ }^{4,5}$, Kremenetskaya I.P. ${ }^{3}$ \\ ${ }^{1}$ Petrozavodsk State University,Petrozavodsk,petrova_anna93@mail.ru \\ ${ }^{2}$ Laboratory of Nature-Inspired Technologies and Environmental Safety of the Arctic KSC RAS, Apatity, \\ slukovskaya.mv@gmail.com \\ ${ }^{3}$ I.V. Tananaev Institute of Chemistry and Technology of Rare Elements and Mineral Raw Materials KSC \\ RAS, Apatity \\ ${ }^{4}$ Institute of North Industrial Ecology Problems KSC RAS, Apatity, korneykova.maria@gmail.com \\ ${ }^{5}$ N.A. Aurorin Polar Alpine Botanical Garden Institute, Apatity, ivanova_la@inbox.ru
}

\begin{abstract}
The results of a field experiment on the remediation of a site with highly polluted peat soil near a copper-nickel plant using a pyroxene product obtained by beneficiation vermiculite-lizardite waste from phlogopite mining (Murmansk region) are presented. On soil mixtures containing 25-100 \% of the product, a vegetation cover was formed using stacking technology with expanded vermiculite obtained from the same waste. The optimal moisture content of soil mixtures was in the variants with 50 and $100 \%$ of pyroxene product. The results of the first summer season showed that in the variant with the ratio of mineral material and peat soil 1:1, the vegetation cover had the highest productivity, and the microbial community had the maximum number of bacteria and fungi. The complex toxicity indicator had values less than 1 in the variants with 75 and $100 \%$ pyroxenite product, and it was 3.3 in the variant $50 \%$. According to the results of the first year, promising approaches of remediation using pyroxene product are the mixing of mineral material with peat soil in a ratio of 1:1 and the formation of a bulk layer.
\end{abstract}

Key words: remediation; heavy metals; Subarctic; mining waste. 


\section{Введение}

Для ремедиации почвенного и растительного покрова в импактной зоне Кольской ГМК предложено использование горнопромышленных отходов, одновременно выполняющих функции геохимических барьеров и сорбентов тяжелых металлов, а также мелиорантов и субстратов для развития растительных и микробных сообществ. Необходимость проведения масштабных работ по локализации загрязнения, накопленного за годы работы предприятия, требуют дальнейших исследований по разработке экономически рентабельной технологии с использованием материалов, способных к выполнению указанных функций. Наиболее нуждающимися в ремедиации являются участки с торфяной почвой, поскольку они приурочены к понижениям мезорельефа и зачастую граничат с природными водоёмами, при этом именно торфяная почва накапливает максимальное количество подвижных, т.е. наиболее токсичных и способных к миграции, соединений тяжелых металлов. Одними из перспективных материалов для крупномасштабных работ по ремедиации на территории Мурманской области являются вермикулит-лизардитовые отходы, образовавшиеся при разработке месторождения флогопита в г. Ковдор.

Цель исследования - выявление возможности использования пироксенового минерального продукта, полученного при обогащении вермикулит-лизардитовых отходов Ковдорского ГОКа в качестве субстратов для фиторемедиации нарушенной и загрязненной торфяной почвы техногенной пустоши.

\section{Схема эксперимента и методы исследования}

Пироксеновый минеральный продукт представляет собой крупнозернистый материал, в состав которого входят пироксены, оливины, а также лизардит и вермикулит, суммарное содержание которых не превышает $10 \%$. В использованном ранее материале - фракции менее 10 мм отходов добычи флогопита - содержание сорбционно-активных минералов составляет 40 \% (Kremenetskaya et al., 2019; Tarasova et al., 2020).

Полевой эксперимент по ремедиации проводился на участке в импактной зоне Кольской ГМК (площадка Мончегорск) с торфяной почвой без растительности (N 67.929761, Е 32.858956). Почвосмеси были сформированы в полевых условиях, для этого поверхностный слой торфяной почвы (0-10 см) был механически гомогенизирован и смешан с минеральным материалом из горнопромышленных отходов (в пропорциях 25/75, 50/50, и 75/25 по объему), контролем являлся вариант

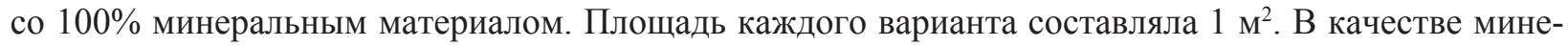
рального материала были использованы «хвосты» обогащения вермикулит-лизардитовых отходов (г. Ковдор, Мурманская обл.), полученные в Горном институте КНЦ РАН при сепарации отходов по гравитационной схеме обогащения (Kremenetskaya et al., 2020). Растительный покров был сформирован по инновационной экспресс-технологии создания ковровой травяной дернины (метод штабелирования), разработанной сотрудниками ФИЦ КНЦ РАН. При этом в качестве субстрата был использован вермикулит, выделенный из этих же отходов в процессе сепарации, и затем обожженный в электропечи. Ковровую дернину стелили на выровненную поверхность почвосмесей, поливали водой и укрывали полиэтиленовой пленкой на 7 дней.

В целом вегетационный сезон 2019 г. был неблагоприятным для произрастания растений, он характеризовался низкими значениями температуры воздуха со средним значением самого теплого месяца (июль) $11.9^{\circ} \mathrm{C}$ и минимальными значениями в июле и августе около $5^{\circ} \mathrm{C}$. Отбор почвосмесей проводился во время закладки эксперимента (июнь) и в конце вегетационного периода (август), растительного материала - в конце августа. Химический анализ проб проводили на базе ИХТРЭМС КНЦ РАН с почвой, высушенной до воздушно-сухого состояния. Содержание подвижных форм элементов определяли после экстракции аммонийно-ацетатным буфером при $\mathrm{pH} 4.65$ и соотношении почвы и раствора 1:4. Полученные растворы анализировали с помощью масс-спектрометра с индуктивно связанной плазмой ELAN 9000 DRC-e (Perkin Elmer, CША). Микробиологические анализы выполняли со свежей почвой на базе лаборатории экологии микроорганизмов ИППЭС КНЦ РАН. Численность культивируемых форм бактерий определяли методом поверхностного посева на 
среду мясо-пептонный агар, количество культивируемых форм микромицетов - методом глубинного посева на среду Чапека с добавлением молочной кислоты из расчета 4 мл на 1 л среды для ингибирования роста бактерий. Чашки Петри инкубировали в термостатах при температуре $27^{\circ} \mathrm{C}$. Учет численности выросших колоний проводили спустя 3 суток для бактерий и 7 суток для грибов методом визуального подсчета с дальнейшим пересчетом на 1 г почвы.

\section{Результаты и обсуждение}

Наиболее интенсивным ростом и биомассой растений характеризовался вариант с объемной долей пироксенового продукта $50 \%$, а наименьшей биомассой - варианты 25 и $75 \%$ (рис. 1). Следует отметить, что вариант с 100 \% минеральным материалом как в июне, так и в сентябре имел более высокую влажность, чем вариант с четвертью торфа, что, вероятно, нашло отражение в большем накоплении биомассы растений в варианте 100 \% по сравнению с 75 \%. Таким образом, продуктивность растений была ограничена высокой долей металлов - с одной стороны, и низкой влажностью - с другой стороны.

Исходная загрязненная торфяная почва в районе предприятия, так же, как и отходы, характеризовалась низкой численностью (50.5 и $31.7 \mathrm{KOЕ/г} \mathrm{почвы} \mathrm{соответственно)} \mathrm{и} \mathrm{разнообразием} \mathrm{ми-}$ кроскопических грибов (табл. 1). Из торфа и отходов выделено по 4 вида микромицетов, принадлежащих роду Penicillium. Внесение пироксенового продукта в концентрации 50 и $75 . \%$ привело к увеличению численности грибов в 4 и 2.5 раза соответственно, вероятно, за счет развития новых видов грибов родов Acremonium, Penicillium и Paecilomyces, что является следствием изменения физико-химических условий. Полученный результат является положительным, поскольку микроскопические грибы - основные деструкторы органического вещества в почве и отвечают за ее плодородие. Спустя три месяца, количество микромицетов увеличилось на порядок почти во всех вариантах опыта, за исключением варианта с $75 \%$ отходов, где оно осталось на прежнем уровне. Наибольшая величина данного показателя была отмечена в варианте с 50 \% отходов.

Численность почвенных бактерий в вариантах с $100 \%$ торфяной почвой и с добавлением $25 \%$ пироксенового продукта была самой низкой и составила 1 и 2.95 тыс. кл/г почвы соответственно. Наибольшее количество бактерий было отмечено в чистых отходах, что можно объяснить щелочной реакцией последних и отсутствием конкуренции со стороны эукариотов. Внесение отходов в загрязненную торфяную почву привело к увеличению численности бактерий и в варианте с 75 \% от-
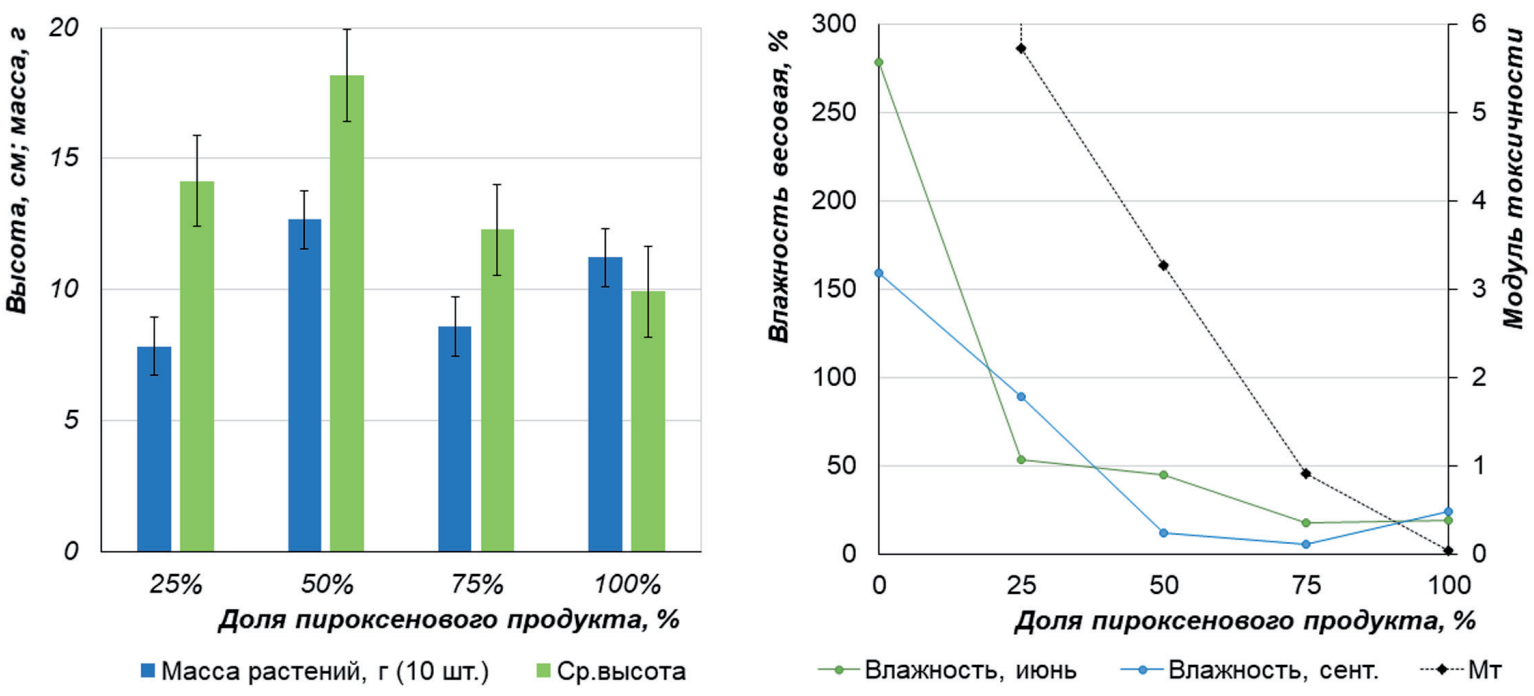

Рис 1. Биометрические показатели растений и влажность почвосмесей в вариантах с различной долей пироксенового продукта.

Fig. 1. Plant biometric indicators and soil moisture in soil mixtures with different proportions of pyroxene product. 


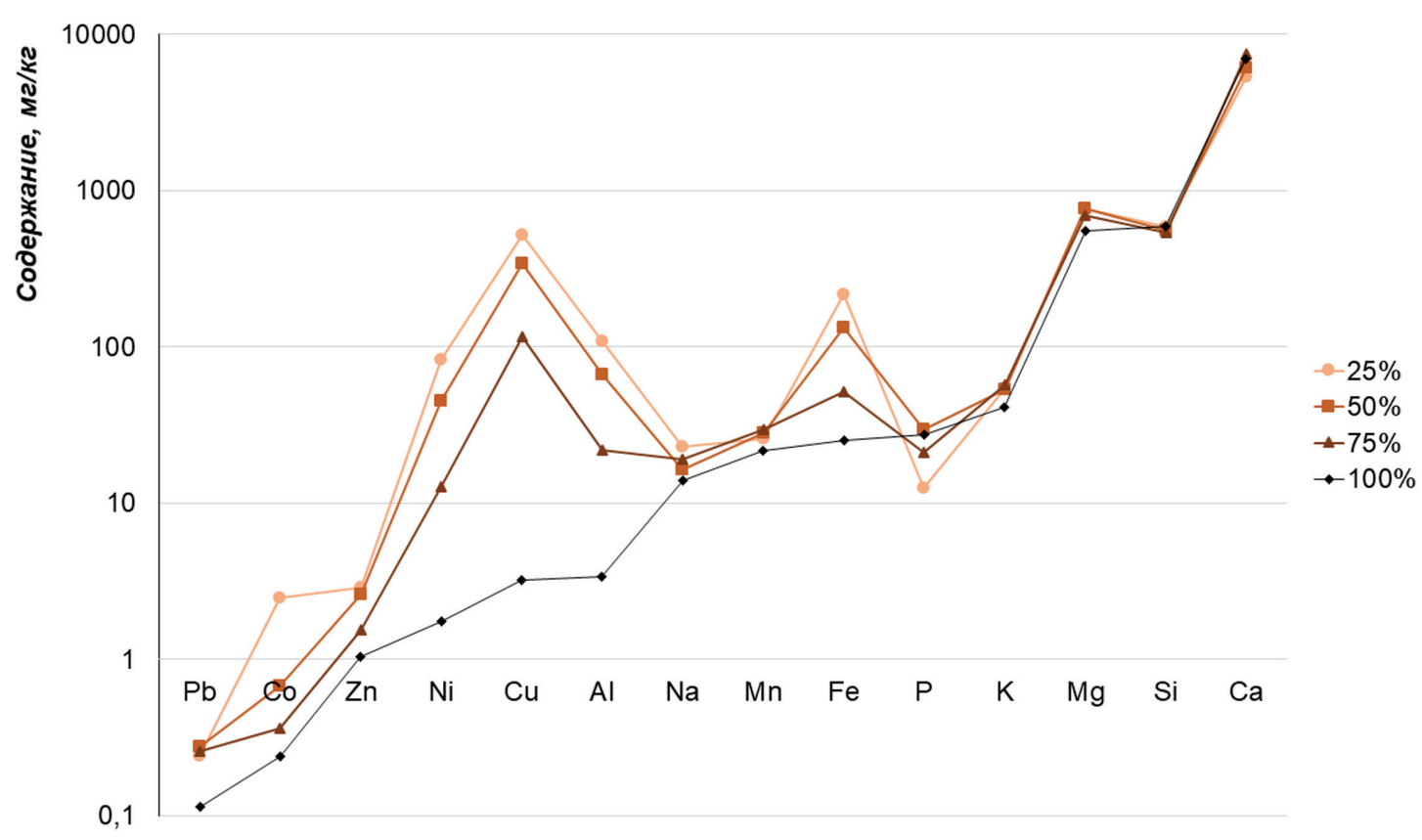

Рис. 2. Содержание обменных форм химических элементов в почвосмесях.

Fig. 2. Content of exchangeable forms of chemical elements in soil mixtures.

ходов достигло значения 296.5 тыс кл/г. К концу вегетационного сезона данный показатель в исходной почве остался на прежнем уровне, в чистых отходах увеличился в два раза, в варианте 75 \% вырос на один порядок, а вариантах $25 \%$ и 50 \% - на три порядка. Как и в случае с микроскопическими грибами, в этом варианте были отмечены несущественные изменения количественных параметров сообществ микроорганизмов. Таким образом, к концу вегетационного сезона вариант с 50 \% отходов характеризовался наибольшей численностью культивируемых форм бактерий и микроскопических грибов, что позволяет говорить о большей микробиологической активности почвы при разбавлении почвы равным по объему пироксеновым продуктом.

Содержание обменной формы меди и никеля в почвосмесях было на 1-2 порядка выше, чем других металлов, и увеличивалось на два порядка по мере увеличения доли торфяной почвы в почвосмеси (рис. 2). Содержание кобальта, который также является элементом-загрязнителем, поступающим в атмосферу и почву с выбросами предприятия, а также железа и алюминия в варианте с 25 \% пироксенового продукта было выше на порядок, чем в варианте с 100 \% минерального материала. Вариации содержания остальных элементов в почвосмесях находились в пределах 1.1-3 раза.

Таблица 1. Численность микроорганизмов в почве и почвосмесях.

Table. Number of microorganisms in soils and soil mixtures.

\begin{tabular}{|c|c|c|c|c|}
\hline \multirow{2}{*}{$\begin{array}{c}\text { Доля пироксенитового } \\
\text { продукта, \% }\end{array}$} & \multicolumn{2}{|c|}{ Численность микромицетов, КОЕ/Г } & \multicolumn{2}{|c|}{ Численность бактерий, тыс. кл/г } \\
\cline { 1 - 4 } & июнь & сентябрь & июнь & сентябрь \\
\hline 0 & $51 \pm 10$ & $484 \pm 46$ & $1 \pm 0.1$ & $10 \pm 2$ \\
\hline 25 & $41 \pm 10$ & $934 \pm 124$ & $3 \pm 0.5$ & $2920 \pm 322$ \\
\hline 50 & $212 \pm 82$ & $3311 \pm 293$ & $62 \pm 3$ & $12546 \pm 8142$ \\
\hline 75 & $125 \pm 32$ & $112 \pm 14$ & $296 \pm 15$ & $8310 \pm 3056$ \\
\hline 100 & $32 \pm 8$ & $290 \pm 30$ & $4630 \pm 2$ & $8394 \pm 1597$ \\
\hline
\end{tabular}

Модуль токсичности, рассчитанный как частное между суммами мольных концентраций $\mathrm{Cu}+\mathrm{Ni}$ и $\mathrm{Ca}+\mathrm{Mg}$, умноженное на 100, имел значение более 50 для исходного торфа, и был равен 5.73 для варианта $25 \%, 3.26$ - для $50 \%, 0.91$ - для 75\%, и 0.04 - для $100 \%$ (рис. 1). Ранее показано, что модуль токсичности, равный единице, является пограничным значением для нормального функци- 
онирования фотосинтетического аппарата злаков и дыхания почв (Слуковская и др., 2017; 2019). В эксперименте с пироксеновым продуктом, вероятно, благоприятные гидрофизические свойства почвосмеси в варианте 50 \% способствовали максимально интенсивному развитию растительного и микробного сообщества, несколько повышая пограничное значение модуля токсичности относительно полученных ранее данных. Мониторинг экспериментальных участков в последующие вегетационные сезоны позволит получить данные о долговременности такого эффекта.

\section{Заключение}

При разработке технологии ремедиации важным является вопрос о лимитирующих фактоpax почвы и почвосмесей. Результаты первого года полевого эксперимента показали, что вариант с 50 \% разбавлением торфяной почвы пироксеновым продуктом являлся наилучшим с точки зрения как продуктивности растений, так и функционирования микробного сообщества. Проведение работ по ремедиации наиболее токсичной торфяной почвы техногенной пустоши путем перемешивания минеральных материалов в пропорции 1:1 с последующим формированием растительного покрова из злаковых растений является реалистичным, экономически рентабельным и эффективным способом восстановления растительности на территориях с загрязненным и деградировавшим почвенным покровом.

Исследование проведено в рамках госзадания по теме НИР 0186-2019-0011, полевые работы выполнены в рамках гранта РНФ 19-77-00077, микробиологические анализы проведены по госзаданию темы НИР № АААА-А18-118021490070-5.

\section{Литература}

1. Слуковская М.В., Новичонок Е.В., Кременецкая И.П., Мосендз И.А., Дрогобужская С.В., Марковская Е.Ф. Применение Festuca rubra L. в фиторемедиации: комплексная оценка влияния техногенного грунта на растение // Ученые записки Петрозаводского государственного университета. 2017. № 4 (165). C. $70-80$.

2. Слуковская М.В., Долгих А.В., Новиков А.И., Мосендз И.А., Кременецкая И.П. Дыхание почв как индикатор токсичности технозёмов // Труды Ферсмановской научной сессии ГИ КНЦ РАН. 2019. 16. C. 529-533. DOI: 10.31241/FNS.2019.16.108.

3. Kremenetskaya I., Tereshchenko S., Alekseeva S., Mosendz I., Slukovskaya M., Ivanova L. and Mikhailova I. 2019. Vermiculite-lizardite ameliorants from mining waste // IOP Conference Series: Earth and Environmental Science. V. 368. 012027. https://doi.org/10.1088/1755-1315/368/1/012027.

4. $\quad$ Kremenetskaya I., Alekseeva S., Slukovskaya M., Mosendz I., Drogobuzhskaya S., Ivanova L. 2020. Expanded vermiculite-reached product obtained from mining waste: the effect of roasting temperature on the agronomic properties // Physicochemical Problems of Mineral Processing. V. 56 (1). P. 103-113. https://doi.org/10.5277/ ppmp19086.

5. Tarasova E., Drogobuzhskaya S., Tapia-Pizarro F., Morev D.V., Brykov V.A., Dovletyarova E. A., Slukovskaya M.V., Navarro-Villarroel C., Paltseva A.A., Neaman A. Vermiculite-Lizardite Industrial Wastes Promote Plant Growth in a Peat Soil Affected by a Cu/Ni Smelter: a Case Study at the Kola Peninsula, Russia // Journal of Soil Science and Plant Nutrition. 2020. P. 1-6. https://doi.org/10.1007/s42729-020-00188-z. 